\title{
INDIAN LEGAL EDUCATION: GOING THE MOOC WAY
}

\author{
Mr. Lagdhir Rabari
}

\section{$\underline{\text { Abstract }}$}

The advent of Information and Communication Technology (ICT), Internet and World Wide Web has made a revolutionary impact on the education. The ICT has opened new avenues in teaching, learning, extension etc., online education being only one of them. With the rise in global competence in expanding education through digital media, India had not remained much behind to make the best possible use of such opportunities. Many law schools in India have already started offering diploma and certificate courses online, so they can accommodate study in law school with added flexibility of time and location, and sometimes with free access to all (MOOC).

The objective of this paper is to present the current status of online education imparted by legal institutes in India. Suggestions are also made for the improvement of such means. Further, the findings show that in line of IITs, IISc, and IIMs, Indian legal institutes are also moving towards online education.

Keywords: MOOC, Online Education, CLAT, Legal Education

\section{Introduction}

MOOC or a Massive Open Online Course, refers to learning in an online environment in the cyber world, thereby providing access to unlimited participants without any limitations as to boundaries and as per convenience to participants. Generally, an online education environment allows a large number of students from across the world to follow online courses. The instructions come online, through various multimedia applications. It also gives an opportunity to students to ask a question, a basic obstacle in online learning mediums, and works on interactive model just like a physical class. Hence, referring a MOOC as a simulation of real time classes is not an exaggeration. On the contrary it also provides access to online multimedia videos which can be uploaded on the system for students to watch it, hear it and extract information in a manner better than traditional learning methods. In addition to this, students can submit their project work, and teachers can conduct online viva as well as online exams. At the end of the course, students are given certificate of passing.

\section{Literature Review}

The review of the published literature on MOOC and open course education gives a broad perspective about MOOC trends, MOOC technology, MOOC status, MOOC systems, need, objectives and benefits. 
Talking about MOOC supply, Delgado, Grima and Bonau (2016) show some differences in cases where prestige is measured by Shanghai ranking and by Webometric ranking. Region and University's nature have a significant influence on MOOC. As stated by Dodson, Kitburi and Berge (2015), there are good possibilities for MOOCs in corporate training and human resources (HR) development. In fact. some authors see MOOCs as the future of education with very few having referred it as disrupter of traditional education. It is safe to say that since last few years, MOOC has been accepted as the best training HR development tool in the corporate world. Making use of the opportunities in the corporate world, MOOC provides learning in a manner which is tailormade to meet organizational needs. Conache, and Dima (2016) argue that MOOC platform has developed considerably in recent years. Their comparative study of four MOOC platforms i.e Coursera, Udemy, U-dacity and EdX., based on its features, users' simplification and demands show that all four rely on the use of multimedia to facilitate MOOC. Udemy tutors can upload videos, audio and zip files, but Coursera, Edx and Udacity work on interactive learning exercise. Richardson and North (2016) state that students can be provided free online MOOC which provides detailed instructions on how to work on every problem. For instance, students who struggle in operational management course can use MOOC as a learning platform to understand concept better.

Despite the great importance of MOOCs in $21^{\text {st }}$ century learning, few papers have dealt with it, especially online courses in legal education. Firzgibbens \& Kelly, sharing their experience of MOOCs, have suggested various legal MOOC learning models like auditory learning, visual learning, readings, writing and social learning. These authors have suggested universities like Leiden and University of London International programme on the level of materials, interaction, assessment and overall experience. Huffman (2016), describing law school teaching practices followed from 1800 to modern times, state that online education is now mainstream, and for non-JD programmes like LLM and ML, it has become widely common. He opines that innovations will improve students' outcome and in coming years, US will employ similar innovations. On the role of libraries in online education, Jaquattee (2015) have underscored the fact that libraries can become a partner in online education. In his survey of 39 respondents, he provides proof of law library's role in teaching legal research online, library lending and access, communication, and staffing pattern requirement. Library as a responding institute must therefore find creative ways to support this new group of users.

\section{Online education scenario in India}

\section{Gujarat National Law University (GNLU), Gandhinagar}

Gujarat National Law University, Gandhinagar offers various online course on law and allied subjects. Altogether six online certificates and diploma course are regularly offered by GNLU. These include two certificate courses in legislative drafting, contract drafting and other diploma courses on varied topics such as Entrepreneurship management and Corporate Laws, Internet Law and Policy, Intellectual Property: Law and Policy, and Sport law. (www.gnluonline.ac.in, last accessed on 17-05-2017).

\section{The West Bengal National University of Juridical Sciences (NUJS), Kolkatta}

NUJS, Kolkata also offers online law courses on various law subjects. "Learn Practical Law Online and Get Certified" is the inviting slogan placed on website by NUJS. The University also offers MA in Business Laws, a two years Masters' programme in online mode. (www.onlinecourses.nujs.edu), (http://mbl.nujs.edu)

\section{Indian Law Institute (ILI), Delhi}


Though Indian Law Institute is not in the category of 18 National Law Universities established in different states, it is a deemed law university, established by the Government of India, at Delhi. ILI, Delhi provides two online certificate courses on topics such as (a) Intellectual Property Rights and Information Technology in the Internet Age, and (b) cyber laws. (www.ili.ac.in).

\section{Indian Institute of Management (IIM), Ahmedabad}

IIM, Ahmedabad is the youngest in the category of pro-MOOC institutes and has recently (2017) started first of its kind of online courses. IIM, Ahmedabad has launched PG diploma in Management (e-PGP). A graduate with $50 \%$ marks can apply and the selection is based on GMAT/CAT score. IIM, Ahmedabad provides good opportunity for those who have dream to study in IIM (www.thehindubusinessline.com, $16^{\text {th }}$ January 2017).

\section{Indian Institute of Management (IIM), Bangalore}

IIM, Bangalore runs various online courses without any cost and also gives an option to students to receive a certificate with payment of a small amount of fees. The online course offered by IIM, Bangalore are: (a) Management economics, (b) Innovations and IT management, (c) Introduction to investment, Entrepreneurship, (d) Business Management, (e) Operations Management, (f) People Management, (g) Corporate Finance, (h) Accounting and Finance, (i) Strategic Management, (j) Customer Relationship Management (CRM), (k) Marketing Management, (l) International Business Environment, (m) Global Strategy, (n) Statistics for Business, Health Care in India and (o) Introduction to Banking and Financial Markets. (www.edt.org/school/iimbx)

\section{Indian Institute of Management (IIM), Kashipur}

IIM, Kashipur offers online courses in various finance, management areas. The courses are offered on varying subjects pertaining to business analysis, digital marketing, marketing analysis and customer valuation, entrepreneurship and on applied financial and risk management.

\section{Indian Institute of Technology (IIT), Bombay}

IITs, Bombay offers online courses through Interactive Classes' mode and MOOC on multiple subjects in various disciplines. The funding for these online courses have been generated from National Mission on Education through ICT and MHRD. Presently IIT, Bombay offers 12 online courses on computers and engineering subjects. (www.iitbombayx.in/partners).

\section{National Programme on Technology Enhanced Learning (NPTEL), IITs and IISc}

National Programme on Technology Enhanced Learning (NPTEL) is a joint initiative of IITs and IISc. NPTEL offers various online course free of cost, and certifications for exams with meagre fees. These courses are offered in association of NASSCOM and funded by MHRD. Currently, for the period July to November 2017, there are 163 MOOC programmes open for admission. (www.onlinecourse.nptel.ac.in).

\section{SWAYAM Online Course}


SWAYAM (Study Webs of Active -Learning for Young Aspiring Minds) is an initiative of Government of India 2016 to achieve access, equity and quality a principles of education policy. SWAYAM offers MOOC course in schools, out of schools, under graduate and post-graduate levels with support of UGNOU, NPTEL, UGC, and NIOS. SWAYAM platform has been designed by MHRD and AICTE with support of Microsoft which has the capacity of hosting 2000 courses or 80000 learning hours.

\section{(https://swayam.gov.in)}

\section{Asian School of Cyber Laws}

Established in 1999, Asian School of Cyber Laws is the first of its kind law school. Asian School of Cyber Laws is a pioneer in cyber law and cybercrime investigations, and works jointly with government, corporates and cyber-crime agencies.

This law school offer courses like diploma in cyber laws, advanced cyber laws and internet crime investigations. In addition to these paid courses, it also offers free online courses in the areas of cryptography, digital marketing, finance law, frau control and tech law.

The basic level course "Diploma in cyber law" is recognized by the government of Maharashtra, and is conducted in collaboration the Government Law College, Mumbai (GLC) India's oldest law college at Mumbai. (http://www.asianlaws.org/index.php)

\section{Research methodology}

The objective of this research is to present the current online and MOOC legal education scenario in India. Spreading the factual and proper information about the legal education on MOOC platform will be greatly beneficial to the librarians, students, academic community and society at large. Library is the right platform to disseminate such information among the users.

This study is based on a quantitative research. The study is carried out by exploring the websites of NLUs, IITs, IIMS, IISc, INFLIBNET, CLAT, BCI, and UGC. In addition, primary data pertaining to NLUs and NLU libraries have been collected through questionnaire from all NLU librarians.

\section{Legal Education in India}

It is safe to say that the Indian legal system is an inheritance of Common Law legal tradition. The Indian legal system and legal education is directly connected with the British legal system, since India was under rule of the British government for some time. (Bar Council of India, 2015).

The cities of Kolkata, Madras and Mumbai were the first centres where formal legal education institutions commenced during the British period. In India, legal education was imparted after graduation (three-year LLB course) by thousands of law colleges established by Government and private organisation recognized by BCI. However, post-independence legal education gained importance due to reforms in legal education and the government later adopted an Integrated five-year law course as a model system of education thereby establishing model National Law Universities.

\section{National Law University System in India}


Legal education is a multi-disciplined, multi-purpose education which can develop the human resources and idealism needed to strengthen the legal system.

In India, legal education was traditionally imparted by Colleges or Universities as a graduate degree, after obtaining basic graduation. However, in a new regulation brought out by the Bar Council of India, a regulating body for legal education and legal profession, it was mandated that law education would henceforth be provided as a five-year integrated course comprising of a basic graduate degree and a degree in law. Another amendment was made by the Bar Council of India later to reduce the two year master's programme in law to one year." (www.bci.ac.in).

However, the credit for this experiment must be given to the establishment of the National Law University, Bangalore (NLSIU) as a first model National Law University in India in 1987. Outstanding success of National Law University concept inspired the legal community to establish more national law universities in India. A policy decision to establish one national law university in each of the Indian states was taken and presently the wheels are still rolling. The Bangalore model was replicated in NALSAR at Hyderabad (1998), NLIU at Bhopal (1999), WBNUJS at Kolkata (2000), NLU at Jodhpur (2001), HNLU at Raipur (2003), GNLU at Gandhinagar (2004), RMLNLU at Lucknow (2006), NUALS at Kochi (2002), CNLU at Patana (2006), RGNUL at Patiala (2006), NLU at Delhi (2008), DSNLU at Visakhapatnam (2008), NLUO at Cuttack (2009) NUSRLR at Ranchi (2010), and NLUJAA (2011). Admission to all these law universities is through national level Common Law Admission Test, commonly referred to as CLAT (Malik, L. \& Arora, M., 2014).

As far as post graduate study is concerned, all universities have instituted a master's degree in law called LL.M. Earlier it was offered for two years but now as per decision and guidelines of UGC, National Law Universities have started one-year LL.M. degree. In addition to these, most universities offer Ph.D. programmes, PG Diploma, Certificate Courses in specializations under distance education mode. (UGC LLM Notification, 2013).

At the moment, these are total number of 16 national law universities in India established since 1987.

Table 1: National Law Universities in India

\begin{tabular}{|l|l|l|l|l|l|}
\hline & National Law Universities & $\begin{array}{l}\text { Est. } \\
\text { Year }\end{array}$ & Faculty & Students & Library Resources \\
\hline 1 & $\begin{array}{l}\text { National Law School of India } \\
\text { University (NLSIU), Bangalore } \\
\text { https://www.nls.ac.in }\end{array}$ & 1987 & 29 & 800 & 58000 Print volumes \\
\hline 2 & NALSAR, Hyderabad & 1998 & 41 & 560 & 29546 Print volumes \\
\hline
\end{tabular}


Towards Excellence: An Indexed, Refereed \& Peer Reviewed Journal of Higher Education / Mr. Lagdhir Rabari / Page 93-105

\begin{tabular}{|c|c|c|c|c|c|}
\hline & https://nalsar.ac.in & & & & 08 Databases \\
\hline 3 & $\begin{array}{l}\text { National Law Institute } \\
\text { University (NLIU), Bhopal } \\
\underline{\text { https://www.nliu.ac.in }}\end{array}$ & 1999 & 21 & 647 & $\begin{array}{l}20000 \text { Print volumes } \\
\text { 05 Databases }\end{array}$ \\
\hline 4 & $\begin{array}{l}\text { National Law Institute } \\
\text { University (NLIU), Jodhpur } \\
\text { www.nlujodhpur.ac.in }\end{array}$ & 2001 & 48 & 675 & $\begin{array}{l}23000 \text { Print volumes } \\
\text { 08 Databases }\end{array}$ \\
\hline 5 & $\begin{array}{l}\text { The West Bengal National } \\
\text { University of Juridical Sciences } \\
\text { (NUJS), Kolkatta } \\
\text { http://www.nujs.edu }\end{array}$ & 2000 & 30 & 700 & $\begin{array}{l}30000 \text { Print volumes } \\
\text { 07 Databases }\end{array}$ \\
\hline 6 & $\begin{array}{l}\text { The National University of } \\
\text { Advanced Legal Studies } \\
\text { (NUALS), Kochi } \\
\text { http://www.nuals.ac.in }\end{array}$ & 2002 & 16 & 510 & $\begin{array}{l}12700 \text { Print volumes } \\
\text { 03 Databases }\end{array}$ \\
\hline 7 & $\begin{array}{l}\text { Gujarat National Law University } \\
\text { (GNLU), Gandhinagar } \\
\\
\text { www.gnlu.ac.in }\end{array}$ & 2003 & 41 & 860 & $\begin{array}{l}35000 \text { Print volumes } \\
12 \text { Databases }\end{array}$ \\
\hline 8 & $\begin{array}{l}\text { Hidayatullah } \\
\text { University of Law (HNLU), } \\
\text { Raipur } \\
\text { https://www.hnlu.ac.in }\end{array}$ & 2003 & 37 & NA & $\begin{array}{l}22778 \text { Print volumes } \\
\text { 06 Databases }\end{array}$ \\
\hline 9 & $\begin{array}{l}\text { Ram Manohar Lohia National } \\
\text { Law University (RMLNLU), } \\
\text { Lucknow } \\
\text { http://www.rmlnlu.ac.in }\end{array}$ & 2006 & 55 & 1000 & $\begin{array}{l}22000 \text { Print volumes } \\
\text { 09 Databases }\end{array}$ \\
\hline 10 & 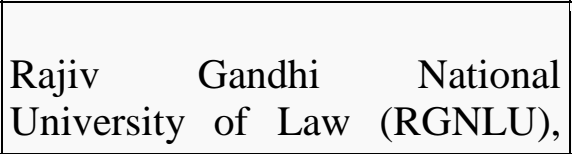 & 2006 & 32 & 730 & 31000 Print volumes \\
\hline
\end{tabular}


Towards Excellence: An Indexed, Refereed \& Peer Reviewed Journal of Higher Education / Mr. Lagdhir Rabari / Page 93-105

\begin{tabular}{|c|c|c|c|c|c|}
\hline & $\begin{array}{l}\text { Patiala } \\
\text { https://www.rgnul.ac.in }\end{array}$ & & & & 14 Databases \\
\hline 11 & $\begin{array}{l}\text { Chankya National Law } \\
\text { University (CNLU), Patna } \\
\text { http://cnlu.ac.in }\end{array}$ & 2006 & 26 & 700 & $\begin{array}{l}13500 \text { Print volumes } \\
\text { 06 Databases }\end{array}$ \\
\hline 12 & $\begin{array}{l}\text { Damodaram } \\
\text { National } \\
\text { University (DSNLU), } \\
\text { Visakhapatnam } \\
\text { https://dsnlu.ac.in }\end{array}$ & 2008 & 10 & 546 & $\begin{array}{l}12922 \text { Print volumes } \\
\text { 04 Databases }\end{array}$ \\
\hline 13 & $\begin{array}{l}\text { National Law University (NLU), } \\
\text { Delhi } \\
\text { www.nludelhi.ac.in }\end{array}$ & 2008 & 55 & 450 & $\begin{array}{l}42500 \text { Print volumes } \\
13 \text { Databases }\end{array}$ \\
\hline 14 & $\begin{array}{l}\text { National Law University Odisha } \\
\text { (NLUO), Cuttack } \\
\text { http://nluo.ac.in }\end{array}$ & 2009 & 33 & 1235 & $\begin{array}{l}7300 \text { Print volumes } \\
13 \text { Databases }\end{array}$ \\
\hline 15 & $\begin{array}{l}\text { National University of Study } \\
\text { and Research in Law (NUSRL), } \\
\text { Ranchi } \\
\underline{\text { http://www.nusrlranchi.in }}\end{array}$ & 2010 & 32 & 600 & $\begin{array}{l}22500 \text { Print volumes } \\
\text { 06 Databases }\end{array}$ \\
\hline 16 & $\begin{array}{l}\text { National Law University and } \\
\text { Judicial Academy Assam } \\
\text { (NUJAA), Guwahati } \\
\underline{\text { http://www.nluassam.ac.in }}\end{array}$ & 2011 & 30 & 300 & $\begin{array}{l}11000 \text { Print volumes } \\
\text { 07 Databases }\end{array}$ \\
\hline 17 & $\begin{array}{lr}\text { Tamil Nadu } & \text { National Law } \\
\text { School } & \text { (TNNLS), } \\
\text { Tiruchirappalli } & \end{array}$ & 2013 & NA & NA & NA \\
\hline 18 & $\begin{array}{l}\text { Maharasthra National Law } \\
\text { University, Mumbai }\end{array}$ & 2016 & NA & NA & NA \\
\hline
\end{tabular}


Towards Excellence: An Indexed, Refereed \& Peer Reviewed Journal of Higher Education / Mr. Lagdhir Rabari / Page 93-105

\begin{tabular}{|l|l|c|c|l|l|}
\hline 19 & $\begin{array}{l}\text { Nagpur National } \\
\text { University, Nagpur }\end{array}$ & 2016 & NA & NA & NA \\
\hline 20 & $\begin{array}{l}\text { Indian Law Institute, New Delhi } \\
\text { (http://ili.ac.in) }\end{array}$ & 1956 & NA & NA & 10 Databases \\
\hline
\end{tabular}

Table 2: Open Education by National Law Universities

\begin{tabular}{|c|c|c|c|}
\hline & National Law Universities & Distance Education Courses & $\begin{array}{l}\text { Online } \\
\text { Courses }\end{array}$ \\
\hline 1 & $\begin{array}{l}\text { National Law School of India } \\
\text { University (NLSIU), Bangalore }\end{array}$ & $\begin{array}{l}\text { MBL, PGDHRL, PGDMLE, GDEL, PGDIPR, } \\
\text { PGDCRL, PGDCLP, PGDCLCF }\end{array}$ & No \\
\hline 2 & NALSAR, Hyderabad & $\begin{array}{l}\text { PGDPL, PGDCL, PGDML, PGIHL (NALSAR } \\
\text { Proximate Education) }\end{array}$ & No \\
\hline 3 & $\begin{array}{l}\text { National Law Institute University } \\
\text { (NLIU), Bhopal }\end{array}$ & No & No \\
\hline 4 & $\begin{array}{l}\text { National Law Institute University } \\
\text { (NLIU), Jodhpur }\end{array}$ & $\begin{array}{l}\text { MS in Cyber law and security, Master in } \\
\text { Intellectual Property and Management. }\end{array}$ & No \\
\hline 5 & $\begin{array}{l}\text { The West Bengal National University } \\
\text { of Juridical Sciences (NUJS), } \\
\text { Kolkatta }\end{array}$ & $\begin{array}{l}\text { PGDCL,PGDPHM, PGDHR, PGDBL, } \\
\text { PGDASL, PGDNL, DEAB }\end{array}$ & Yes \\
\hline 6 & $\begin{array}{l}\text { The National University of Advanced } \\
\text { Legal Studies (NUALS), Kochi }\end{array}$ & PGDMLE, PGDCY & No \\
\hline 7 & $\begin{array}{l}\text { Gujarat National Law University } \\
\text { (GNLU), Gandhinagar }\end{array}$ & No & Yes \\
\hline
\end{tabular}


Towards Excellence: An Indexed, Refereed \& Peer Reviewed Journal of Higher Education / Mr. Lagdhir $\underline{\text { Rabari / Page 93-105 }}$

\begin{tabular}{|c|c|c|c|}
\hline 8 & $\begin{array}{l}\text { Hidayatullah National University of } \\
\text { Law (HNLU), Raipur }\end{array}$ & No & No \\
\hline 9 & $\begin{array}{l}\text { Ram Manohar Lohia National Law } \\
\text { University (RMLNLU), Lucknow }\end{array}$ & No & No \\
\hline 10 & $\begin{array}{l}\text { Rajiv Gandhi National University of } \\
\text { Law (RGNLU), Patiala }\end{array}$ & No & No \\
\hline 11 & $\begin{array}{l}\text { Chankya National Law University } \\
\text { (CNLU), Patna }\end{array}$ & No & No \\
\hline 12 & $\begin{array}{l}\text { Damodaram Sanjivayya National Law } \\
\text { University (DSNLU), Visakhapatnam }\end{array}$ & PGDADR & No \\
\hline No & $\begin{array}{l}\text { National Law University (NLU), } \\
\text { Delhi }\end{array}$ & DCCPL & No \\
\hline 14 & $\begin{array}{l}\text { National Law University Odisha } \\
\text { (NLUO), Cuttack }\end{array}$ & $\begin{array}{l}\text { Advance vocational diploma in paralegal } \\
\text { studies }\end{array}$ & No \\
\hline 15 & $\begin{array}{l}\text { National University of Study and } \\
\text { Research in Law (NUSRL), Ranchi }\end{array}$ & No & No \\
\hline 16 & 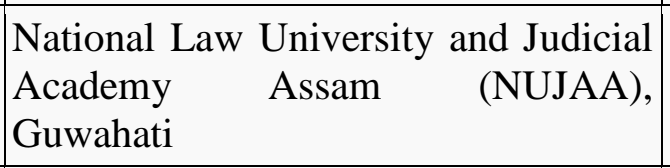 & No & No \\
\hline 17 & $\begin{array}{l}\text { Tamil Nadu National Law School } \\
\text { (TNNLS), Tiruchirappalli }\end{array}$ & No & No \\
\hline 18 & $\begin{array}{l}\text { Maharashtra National Law } \\
\text { University, Mumbai }\end{array}$ & No & No \\
\hline 19 & $\begin{array}{l}\text { Nagpur National Law University, } \\
\text { Nagpur }\end{array}$ & No & No \\
\hline 20 & Indian Law Institute, New Delhi & No & Yes \\
\hline
\end{tabular}

Admission scenario for the National Law Universities

DEC, 2017. VOL.9. ISSUE NO. 3 
The admission in these National Law Universities is offered through Common Law Admission Test (CLAT), except NLU, Delhi, which conducts its separate admission test call All India Law Entrance Test (AILET). Until 2017 NLU-Delhi is not a part of CLAT participating Universities. CLAT is conducted every year by NLUs on rotation basis, the first being conducted by NLSIU, Bangalore in 2008, and the recent 2017 CLAT being coordinated by CNLU, Patna on May 14, 2017. Admission to both UG (LLB) and PG (LLM) courses in India is done through CLAT score. LLB is offered in various streams such as BA LLB, BCOM LLB, BSc LLB, BBA LLB and BSW LLB. In compare to total intake capacity of 2165seats, more than 47000 thousand students attend the test and these numbers are increasing day by day.

Table 3: CLAT Appeared Students

\begin{tabular}{|l|l|l|l|}
\hline $\begin{array}{l}\text { Sr. } \\
\text { No. }\end{array}$ & CLAT coordinator NLU & CLAT Year & CLAT Attended \\
\hline 1 & NLSIU, Bangalore & 2008 & 11000 \\
\hline 2 & NALSAR, Hyderabad & 2009 & 15000 \\
\hline 3 & NLIU, Bhopal & 2010 & 18375 \\
\hline 4 & NUJS, Kolkata & 2011 & 24256 \\
\hline 5 & NLU, Jodhpur & 2012 & 25769 \\
\hline 6 & HNLU, Raipur & 2013 & 39915 \\
\hline 7 & GNLU, Gandhinagar & 2014 & 37358 \\
\hline 8 & RMNLU, Lucknow & 2015 & 37231 \\
\hline 9 & RGNLU, Patiala & 2016 & \\
\hline
\end{tabular}




\begin{tabular}{|l|l|l|l|}
\hline 10 & CNLU, Patna & 2017 & 47108 \\
\hline
\end{tabular}

(Source- www.legalindia.com, www.lawcareer360.com, www.hindustantimes.com, $14^{\text {th }}$ May 2017)

\section{Findings and Suggestions}

\section{Findings:}

- Establishment of National Law Universities is India was a major step in legal education reforms.

- National law universities in India were established in two phases. First phase was before 1990 and second phase after 1997.

- Average faculty strength of these National law universities is between 20 to 45 .

- Indian legal system follows common law tradition, hence law degrees in Indian law universities are referred as LLB, LLM or Ph.D. These law universities offer five-year integrated LLB and one-year LLM courses.

- Average students' strength in these National Law Universities is between 400 to 1000.

- The ICT infrastructure of almost all National Law Universities is well developed.

- National Law University libraries are spending huge amount on acquisition of various library resources. On average, almost all National Law University spend approximately 50-90 lakh rupees per annum.

- Almost all NLUs offer distance learning education programmes and other law related short-term training and development programmes.

- There are few National Law Universities which offer MOOC courses too.

- Previous trends in relation to obtaining admissions in NLUs indicate that these numbers are increasing every day.

- Some challenges can be seen on technological and IPR related issues. However, being law universities, it is without doubt that these universities would be able to find out solutions to these issues.

- The platform to offer online courses are not developed at standard level as far as technology is concerned. Almost all institutes in India which offer online courses have collaborated with several corporate companies for technology related issues. However, there is not much initiative within the institutes themselves to develop this platform.

\section{Suggestions:}

1. Standard MOOC platform is an immediate requirement to develop online legal education programmes.

2. In varying ways, all National Law Universities are associated with each other. Hence, starting the same collaboration for MOOC purpose is also not difficult, assuming high cooperation is present among these universities .

3. Majority of the NLUs are new and hence it may be the right time to start such online courses in the larger interest of the students.

4. It is possible to have common syllabus, common course outlines, common exam papers through MOOC and there is also a good opportunity to start online courses with support of each other.

5. These NLUs can start online courses in groups, akin to IITs and IISc collaboration as can be seen through "National Programme on Technology Enhanced Learning (NPTEL)" model. 
6. Online learning is the best alternate education solution for India to give an opportunity to everyone who is willing to learn. MOOC platform and policy has to be designed, developed by the UGC and MHRD. Policy, platform and technological development is an emergency requirement to make these courses perfect.

7. NLUs can help MHRD and UGC to develop standard online education policy.

8. NLUs can also prepare the policy documents on copyright, IPR and contract related issues, since they fall within the domain subjects for various NLUs.

9. The infrastructure, faculty strength, faculty experiences, expertise, library resources and standard of these National Law Universities have huge potential to take a lead in MOOC programme.

10. INFLIBNET has developed good online video lectures "E-Pathshala", so the NLUs can take help of INFLIBNET centre to develop such online lectures, videos for their MOOC courses.

\section{Conclusion}

The study provides a clear and comprehensive understanding of MOOC trends in Indian legal education. The introduction part deals with the profiles of National Law Universities and their libraries. The paper gives a complete status of NLUs various distance education and online programmes. Like IIMs, IITs and IISc, the National law universities have also have initiated online mode of education to encourage legal learning for all.

The findings of this study show that there is huge demand to pursue law in such NLUs. Against the intake capacity of 2165 seats in Indian national law universities more than 47000 students appear in the admission test (CLAT). In addition to these, a huge number of executives, practicing lawyers, academicians who want to join some legal and para legal courses in these universities can opt for the same, courses spanning across the domains of Intellectual Property Rights, Cyber laws, Contract laws etc. So, MOOC is the best solution to fulfil the need and demand of the society by offering such online courses. Continuous training for judiciary, government officials and corporate word is also possible since such workforce comprise of working people who are not able to give time for regular courses.

National Law Universities in India have adequate infrastructure, resources, faculty and expertise. These National Law Universities have the capacity to make legal education open for all, including those who want to pursue law for practice, law for governance, law for reform, law for social work or law for its own interest.

\section{$\underline{\text { References }}$}

1. Megan Fitzgibbons and Kim Kelly (2013). MOOCs as Online Professional Developmnnt for L aw Librarians. Australian Law Librarians, 21(4), 245-252

2. Huffman, Max (2015), Online Learning Grows Up and Heads to Law School. Indiana Law Review, 49, 57-84

3. Jaquette , Ellen Q. (2015), Online Education and the Law Library How can we best serve our online patrons? AALL Spectrum, 33-34

4. by Michele Nicole, Karat Kitburi, \& Zane L. Berge, (2015), Possibilities for MOOCS in Corporate. Training and Development Performance Improvement, 54 (10), 14-21

5. Maria CONACHE, Ramona DIMA \& Andreea MUT,A (2016), Comparative Analysis of MOOC Platforms. Informatica Economică, 20 (2), 5-14 
6. Julieth E. Ospina-Delgado1, Ana Zorio-Grima, María A.(2016), García-Benau2Massive open online courses in higher education: a data analysis of the MOOC supply. Intangible Capital, 12(5), 1401-1450

7. Ronny Richardson, Max North (2016), Using a MOOC to Supplement Classroom Teaching in a Quantitative Course. International Management Review, 12 ( 2), 43-48

8. Malik, L. \& Arora, M. (Eds.), (2014). Legal education in India: Essays in honour of Professor Ranbir Singh. Delhi: Universal Law Publishing.

\section{Web Sites:}

1. http://www.clat.ac.in

2. http://www.ugc.ac.in

3. www.bci.ac.in

4. www.inflibnet.ac.in

\section{Abbreviation Explanations}

1. Post Graduate Diploma in Cyber Law (PGDCL)

2. Post Graduate Diploma in Medical Law and Ethics (PGDMLE

3. Post Graduate Diploma in Alternate Dispute Resolution (PGDADR)

4. Diploma Course in Competition Policy and Law (DCCPL)

5. PG Diploma in Patents Law (PGDPL)

6. PG Diploma in Cyber Laws (PGDCL)

7. PG Diploma in Media Laws (PGDML)

8. PG Diploma in International Humanitarian Law (PGDIHL)

9. Master of Business Laws (MBL)

10. Post Graduate Diploma in Human Rights Law (PGDHRL)

11. Post Graduate Diploma in Medical Law and Ethics (PGDMLE)

12. Post Graduate Diploma in Environmental Law (PGDEL)

13. Post Graduate Diploma in Intellectual Property Rights Law (PGDIPRL)

14. Post Graduate Diploma in Child Rights Law (PGDCRL)

15. Post Graduate Diploma in Consumer Law \& Practice (PGDCLP)

16. Post Graduate Diploma in Cyber Law \& Cyber Forensics (PGDCLCF)

17. PG Diploma in Public Healthcare and Medical Laws (PGDPHM)

18. Post Graduate Diploma in Human Rights (PGDHR)

19. Post Graduate Diploma in Business Laws Programme (PGDBL)

20. Post Graduate Diploma in Air and Space Law (PGDASL)

21. Post Graduate Diploma in Nuclear Law (PGDNL)

22. Diploma in Entrepreneurship Administration and Business Laws (DEAB)

\section{Mr. Lagdhir Rabari}

Head, Library and Language Services Division

Gujarat National Law Univeristy

Koba-Gandhinagar, Gujarat, lrabari@gnlu.ac.in 